\title{
Representações do arcaico: João Cabral de Melo Neto e Clarice Lispector
}

Arthur Grupillo

Cicero Cunha Bezerrab

\begin{abstract}
Resumo
Tratar de dois autores como João Cabral e Clarice Lispector é, no minimo, desafiador. Misturar poesia e conto em uma análise comparativa exige um esforço duplo: primeiro, ao interpretá-lo, não reduzir o poético ao meramente analítico e, segundo, não perder, do conto, sua concisão poética. O presente artigo tem, não obstante, um eixo central: refletir sobre a imagem do "ovo" presente nos dois autores, evidenciando divergências e conciliações que permitam pensar, do ponto de vista literário, uma compreensão do arcaico que se manifesta, precisamente, no cotidiano.
\end{abstract}

Palavras-chaves: João Cabral, Clarice Lispector, ovo, arcaico

\footnotetext{
a Universidade Federal de Sergipe, aegrupillo@gmail.com

b Universidade Federal de Sergipe, cicerobezerra@hotmail.com
} 


\section{Considerações iniciais}

A obra de arte, a obra literária - não é acabada nem inacabada: ela é. O que ela nos diz é exclusivamente isso: que é - e nada mais.

Fora disso, não é nada (Blanchot, 2001, p. 12).

1 Como se sabe, a arquitetura modernista exerceu tamanha influência no pensamento de Cabral que ele afirmou, certa vez: "Todo mundo tem que ter na vida o seu filósofo, né? Que é o filósofo que teve importância na sua vida. Na minha vida o meu filósofo não era filósofo, era um arquiteto. Era o Le Corbusier" (MELO NETO, 2009).

2 A paginação em algarismo romano se refere ao material de apoio à Poesia Completado autor, editada primeiramente em 1994, e posteriormente em 2007. A organização do material deve-se a Antonio Carlos Secchin.
O Ovo de Galinha é talvez um dos poemas mais eloquentes de João Cabral de Melo Neto, precisamente por tratar meramente de "um ovo". Com a expressão de artigo indefinido, "um ovo", se quer dizer "uma coisa", e uma coisa indefinida. Esta expressão, contudo, como veremos, é frequentemente contraposta a "o ovo", que define o ser daquele algo indefinido, para além do artigo. "Ovo" pertence ao campo semântico de matriz mito-poética, arcaica, que de imediato choca com o estilo cabralino aparentemente moderno e formalista (NUNES, 2009, p. 164; VILLAÇA, 1996, p.152). Este poema é, portanto, exemplar, na explanação da problemática de sua poesia, determinada por uma noção dupla e existencial de rigor.

Certamente, no caso de Cabral, não se pode negar a preocupação com a constituição formal do poema, sua métrica, seu ritmo, a famosa rima toante, que desenvolveu melhor do que ninguém, a sintaxe marcada por repetições e aliterações que fazem lembrar o martelo e a bigorna, constituindo a música sem música de sua poesia, o seu metrônomo ou pêndulo, a máquina paciente e útil que, surpreendentemente, se encontra também numa fruta. Tudo isto compõe um primeiro sentido de rigor, formalista, mental, arquitetônico. ${ }^{1}$ Mas o próprio Cabral, no contexto do modernismo brasileiro, entre o verso livre e a poesia concreta, havia esclarecido, sem deixar dúvidas: "Eu acho que já era o momento de se voltar a uma forma rígida. Não de voltar a nenhum Parnasianismo, sonetismo, a nenhuma forma rígida exterior. Mas eu tenho a impressão de que cada pessoa deveria encontrar a sua forma rígida para sua maneira de ser e segui-la." (MELO NETO, 2007, p.xxx) ${ }^{2}$. Por isso, quando está em questão a poesia de João Cabral, é fundamental e de extrema importância, sob o risco de mal compreendê-lo, enfatizar que um segundo rigor, a que chamarei de "fenomenológico", vem necessariamente juntar-se ao primeiro.

Este é instituído pelo compromisso altamente responsável de dizer o abstrato unicamente através do concreto, jamais em si mesmo. Trata-se do esforço de enxergar e dar a ver o 
3 Contrapõem-se, aqui, duas grandes referências de Cabral: o arquiteto Le Corbusier e o pintor Joan Miró. Junta-se a elas a influência de Murilo Mendes, de quem Cabral afirma: "Nenhum poeta brasileiro me ensinou como ele a importância do visual contra o conceitual, do plástico sobre o musical. A poesia dele, que tanto parecia gostar de música, é muito mais de pintor ou cineasta do que de músico. Sua poesia me ensinou que a palavra concreta, porque sensorial, é sempre mais poética do que a abstrata, e que, assim, a função do poeta é dar a ver" (MELO NETO, 2007, p.xxxvii).

4 Affonso Romano De Sant'Anna ressalta um dos aspectos centrais dos contos de Clarice, a saber: o epifânico. A revelação a partir de experiências rotineiras que tem no aspecto antilógico da linguagem, a expressão de uma luta bem próxima da linguagem heraclítica de um logos marcado pelo antagonismo. Cf. ROMANO, Affonso, 2013, p.89. poético na matéria elementar: a água, o mineral, a mucosa, o ósseo. Este outro rigor é, diferentemente daquele, semântico, pessoal e pictórico (MELO NETO, 1997, p.14)3. "A imagem", ressaltou o poeta para as câmeras de um documentário, "é tanto mais eloquente quanto mais diferentes são as realidades que ela aproxima" (MELO NETO apud MESEL, 1997). Assim se compreende, por exemplo, a "inquietação de faca/que há nos peixes" (Idem, 2007, p.82) ou que "o mar podia ser uma bandeira/azul e branca/desdobrada/no extremo do curso - ou do mastro - do rio" (Ibidem, p.87).

Já o conto O Ovo e a Galinha, de Clarice Lispector, é tido, por ela mesma, como o mais incompreensível de toda a sua obra (LISPECTOR, 1977). Curiosamente, a autora o coloca com um dos dois mais importantes, exatamente pelo caráter de mistério, entenda-se de incompreensibilidade, que o envolve. De fato, é impossível, para o leitor, não ficar desconcertado diante de uma narrativa que transita de uma experiência cotidiana como ir a uma cozinha ${ }^{4}$ e ver um ovo a uma relação entre indivíduo e cosmos marcada por um destino que ultrapassa o indivíduo e o faz instrumento de preservação de um processo geracional que é a própria vida.

Evandro Nascimento define o "ovo" de Clarice como um quase objeto, ou seja, como o óbvio, mas, também, como o que se furta aos jogos especulares da ratio ocidental (2012, p.50). Mas essa imagem do "quase" não nos parece acertada. Se o ovo se furta à razão, não é porque carregue uma não objetividade. $\mathrm{O}$ ovo é íntegro. É corpo. Nesse sentido, não há quase quando a experiência é plena, ou melhor, quando o visível, seguindo a ótica merleaupontiana, permite uma abertura para o invisível (Merleau-Ponty, 2004, p.43). Se o ovo coloca em xeque a razão ocidental isso ocorre, exatamente, porque não se contrapõe a ela, mas escapa às suas dicotomias mais elementares. Partimos, assim, da ideia de que o ovo é visto em toda sua inteireza. $\mathrm{O}$ ovo é supervisível.

\section{João Cabral: o ovo e seus contrapontos}

Para Cabral, a competência metafórica é entendida como desafio de encontrar o poético ali onde nada se suspeitaria poético. Tal exercício, contudo, não se caracteriza por inversões 
dialéticas óbvias, tais como "regiões onde tudo é surpresa/ como uma flor mesmo num canteiro" (MELO NETO, 2007, p.55), que pelo menos neste caso explora inteligentemente a obviedade - mas como hermenêutica do elementar: a pedra, a lama, o coágulo. Com efeito, é um desafio de "enxergar", como já havia explicado Cabral a partir da fórmula de Pedro Nava, "o sentido oculto do inerte" (MELO NETO, 1997, p.14).

O ovo é, em si mesmo, estas duas coisas numa só, oculta e inerte. O poeta que se esforça para decifrar o morto no vivo, ou o vivo no morto, encontra no ovo o encontro dessas coisas, sem esforço. $\mathrm{O}$ ovo é, neste sentido, imagem que se doa à própria concepção da matéria em João Cabral. Poderia ser uma imagem fácil, mas precisamente por isso está constantemente sob a ameaça de decair, como um ovo qualquer. O poeta precisa trabalhar com as faces aparentes e ocultas do ovo na confluência e na contraposição de diferentes capacidades sensíveis, como a visão e o tato, que por fim se encontram e se contrapõem num sentido comum, a "presença" do ovo.

Como o presente trabalho quer tentar explicitar estes rigores, diferentes e complementares, com a descrição da forma, de um lado, e com o mapeamento semântico, de outro, ocorreu-nos, sem perder de vista o todo, investigar o poema parágrafo por parágrafo e, mesmo sabendo do amplo conhecimento que dele se tem, transcrevê-los na íntegra (MELO NETO, 2007, p.278-9). São quatro, como um quadrado de arestas definidas, constituídos de quatro estrofes cada um, compostos de quatro versos octossílabos, contudo altamente variantes, com cesuras bastante heterodoxas, ora na $4^{\mathrm{a}}$ e $8^{\mathrm{a}}$ sílabas, ora na $2^{\mathrm{a}}, 5^{\mathrm{a}}$ e $8^{\mathrm{a}}$ sílabas, sendo estas as mais tradicionais, mas também na $2^{\mathrm{a}}, 6^{\mathrm{a}}$ e $8^{\mathrm{a}}$ sílabas ou $3^{\mathrm{a}}, 6^{\mathrm{a}}$ e $8^{a}$ sílabas. A estrutura, portanto, serve ao poema, e não o contrário. O ritmo é um elemento de pausa, de erupção, de aparo, de choque com a palavra resistente, e não de melodia e musicalidade. Na verdade, arriscaríamos dizer que os dois rigores, com frequência equilibrados nos poemas de Cabral, aqui tendem com grande força para a expressão, constituindo uma predominância sutil do pictórico sobre o arquitetônico. Acreditamos ser esta uma hipótese de longo alcance, que talvez se pudesse perscrutar em toda a obra de Cabral. 


\section{Parágrafo primeiro}

Ao olho mostra a integridade de uma coisa num bloco, um ovo.

Numa só matéria, unitária, maciçamente ovo, num todo.

Sem possuir um dentro e um fora, tal como as pedras, sem miolo: e só miolo: o dentro e o fora integralmente no contorno.

No entanto, se ao olho se mostra unânime em si mesmo, um ovo, a mão que o sopesa descobre que nele há algo suspeitoso: que seu peso não é o das pedras, inanimado, frio, goro; que o seu é um peso morno, túmido, um peso que é vivo e não morto.

Nesta primeira parte do poema, a contraposição já está colocada. O título já pertence, pela sintaxe entrevista, ao primeiro verso: "O ovo de galinha" exibe a integridade típica de uma coisa num bloco, por exemplo: "um ovo". Exibe, contudo, "ao olho", expressão com a qual o verso e o poema propriamente dito têm início. O primeiro elemento da contraposição é o olhar. Para o sentido da visão, o ovo não passa de um bloco, o ovo não passa de um ovo. "Um ovo" tem caráter adjetivo, ao contrário do "ovo de galinha", substantivo, distinto e distinguido. Para o sentido da visão, restam apenas adjetivos, a característica de integridade da matéria pura, num todo. Ao olho, um ovo é algo, portanto, "maciçamente ovo". Esta ocorrência da palavra, neste verso, é sutilmente adjetiva.

Ao olho, da mesma forma, não se distingue dois lados, o de dentro e o de fora, do ovo, assim como ocorre às pedras, às coisas sem miolo ou "só miolo", o que dá no mesmo. Trata-se de coisas sem determinações maiores para o olhar. Como este só enxerga o contorno, tudo se resolve e se resume nele, como se nada houvesse ali para ser descoberto. As duas primeiras estrofes se limitam a isto: à falta de interesse, inclusive poético, que ao olho se mostra um ovo, como coisa bruta, sem determinações e sem surpresa. O contraponto se esclarece no 
princípio da terceira estrofe com: "No entanto...". Se de um lado temos unanimidade, de outro temos suspeita, que, no entanto, se revela, não "ao olho", mas à "mão", que o sopesa. Aqui ocorre descoberta, mas uma descoberta ao mesmo tempo indeterminada - que apenas rompe com o maciço e o unânime iniciais - e extremamente promissora, que pode conter calor e ocultar vida. Tal suspeita torna-se acessível a partir de um movimento de aproximação. O olho que apenas vê o ovo, toca-o, sopesa-o, e do peso sente a suspeita, de outra forma inacessível. O primeiro parágrafo se limita a dispor esta contraposição apenas, e, contudo, fundamental.

Por fim, para o olho, as coisas são dentro assim como são fora. É isto que significa "integralmente no contorno". Mas parece que o poema é ele mesmo feito com o contorno dos versos. Os versos contornam o objeto: repetições de "ovo", "todo", "dentro" e "fora". Duas vezes ocorre "miolo", duas vezes ocorrem "dentro e fora", também duas vezes a mesma ideia de "integridade/integralmente". O poeta faz com os versos um movimento de raspagem, um gesto repetitivo, que vai aparando as arestas do objeto, difícil de apreender. Um movimento que, afinal, encontra sua perfeita aplicação no próprio ovo, enquanto objeto que se adéqua, como disse, à concepção poética mesma.

Parágrafo segundo

O ovo revela o acabamento

a toda mão que o acaricia, daquelas coisas torneadas num trabalho de toda a vida.

E que se encontra também noutras que entretanto mão não fabrica: nos corais, nos seixos rolados e em tantas coisas esculpidas, cujas formas simples são obra de mil inacabáveis lixas usadas por mãos escultoras escondidas na água, na brisa. No entretanto, o ovo, e apesar de pura forma concluída, não se situa no final:

está no ponto de partida. 
5 De O Cão sem Plumas: "Uma bandeira/ que tivesse dentes:/ que o mar está sempre/com seus dentes e seu sabão/roendo suas praias./Uma bandeira/que tivesse dentes:/ como um poeta puro/ polindo esqueletos,/ como um roedor puro,/ um polícia puro/elaborando esqueletos,/o mar,/com afã,/está sempre outra vez lavando/seu puro esqueleto de areia./O mar e seu incenso,/o mar e seus ácidos,/o mar e a boca de seus ácidos,/o mar e seu estômago/que come e se come,/o mar e sua carne/vidrada, de estátua,/seu silêncio, alcançado/à custa de sempre dizer/a mesma coisa,/o mar e seu tão puro/professor de geometria."
Este movimento de doação, de encontrar, por assim dizer, já acabado ou pronto, no objeto específico ovo, o trabalho que o poeta tem de fazer para dar a ver seu objeto, é revelado no primeiro verso da primeira estrofe deste parágrafo segundo. $\mathrm{O}$ ovo revela seu acabamento. Já não se trata mais de um "sopesar", que é ao mesmo tempo um inspecionar, diante da suspeita. Trata-se de uma mão convidada a acariciar, estimulada a constatar o fino acabamento da coisa, e encontrar nela o que é típico "daquelas coisas torneadas" por um trabalhamento infinito, de toda a vida. Cumpre ressaltar aqui, além disso, a ressonância de "toda mão" e "toda vida", designando sentidos distintos do "todo", enquanto generalidade e universalidade formais, de um lado, e enquanto inteireza e completude substanciais, de outro.

O mar possui, na poesia de Cabral, o lugar ideal, ascético e asséptico, quase místico, do trabalhador incansável, "professor de geometria" (2007, p.87-8) . Por isso, à mão que acaricia o ovo é revelado o trabalho que "entretanto mão não fabrica". Os corais e seixos rolados, aparentemente sem arestas, simples como é "um ovo" assim poderia ser também "um seixo" - sem importância, na verdade são obra de "mil inacabáveis lixas", como as que o poeta tenta imitar, desocultá-las, escondidas que estão, "na água, na brisa".

Os contrapontos fazem o trabalho repetitivo, de lixa ou de traçador, pautado pela sintaxe adversativa. Se ao olho se mostra, "no entanto" a mão descobre. Se a mão descobre, "entretanto" mão não fabrica. É no entretanto e no apesar que está o ovo. Embora assim, coisa acabada, pronta, aparada e lixada, "forma concluída", do ponto de vista de sua forma, o ovo não está no ponto final, mas no ponto de partida, do ponto de vista de seu conteúdo. Tais contrapontos revelam, também, a contraposição fundamental entre o formal e o semântico, o moderno e o arcaico, em que a poesia de João Cabral se move repetidamente. A coisa ovo designa algo que está no começo, e não no final, contrariando tanto o olho quanto a mão. Mas o poeta resiste em revelar o que há dentro do ovo. O poeta, se deve ser capaz de enxergar o sentido oculto do inerte, o vivo do morto, deve ser capaz de dar a ver o ovo sem quebrá-lo. Deve nos mostrar o seu dentro simplesmente no seu fora. Dentro e fora devem permanecer, como permanecem no ovo, "integralmente no 
contorno". Aparar arestas é um comportamento inteiramente avesso à violência, à quebra, à ruptura, à rachadura. É a algum sentido, mesmo que não ao olho ou à mão, que o ovo realmente se revela. Isto será sua "presença".

Parágrafo terceiro

A presença de qualquer ovo, até se a mão não lhe faz nada, possui o dom de provocar certa reserva em qualquer sala. O que é difícil de entender se se pensa na forma clara que tem um ovo, e na franqueza de sua parede caiada.

A reserva que um ovo inspira é de espécie bastante rara: é a que se sente ante um revólver e não se sente ante uma bala.

É a que se sente ante essas coisas que conservando outras guardadas ameaçam mais com disparar do que com a coisa que disparam.

Novamente, é um contraponto que abre a cena. Mesmo se a mão, a mesma que o acariciou e a quem se revelou coisa acabada e finalizada, nada faz ao ovo, a presença deste se impõe. Esta presença é tão imperativa que supera a distinção entre "um ovo" e "o ovo", entre o singular e o universal, marcada pela ressonância, desta vez equivalente, entre "qualquer ovo" e "qualquer sala". Ela é marcada por um "dom", uma capacidade inerente de provocar reserva onde quer que esteja presente. Na verdade, esta presença se impõe mesmo contra o olho e a mão. Ela é difícil de entender, pois para o olho o ovo é forma clara, e para o tato, sua parede caiada inspira franqueza e sinceridade. "Parede caiada" é, além disso, semântica própria da casa, da sala, inspirando, além de franqueza e sinceridade, também familiaridade e confiança. O ovo seria algo completamente inofensivo, se sua ameaça não fosse de "espécie bastante rara". É aqui que toma lugar o trabalho duplo do poeta, não meramente formal, mas de perscrutar, mais uma vez, o sentido oculto do inerte, o poder exemplar na metáfora, que é tanto 
6 Parafraseio aqui a Wittgenstein, cuja famosa metáforado besouro na caixa, mutatis mutandis, se aplica ao caso. Cf.WITTGENSTEIN, 1979, p.105 mais eloquente quanto mais diferentes são as realidades que ela aproxima. E que metáfora! Encontramo-nos no clímax, formal e semântico, do poema: essa reserva ou ameaça "bastante rara" é "a que se sente ante um revólver/e não se sente ante uma bala." A oposição formal, ressaltada pelas expressões repetidas e intocadas "se sente ante" e "não se sente ante", faz convergir toda atenção para as palavras contrapostas, "revólver" e "bala", que embora pertençam ao mesmo campo semântico, e pertençam mesmo uma à outra, aqui se opõem, porque a bala ameaça com o que efetivamente $f a z$ ou pode fazer, o revólver, pelo contrário, ameaça simplesmente com sua presença. Que haja uma bala ou não realmente dentro do revólver é algo que cai fora de consideração, como irrelevante. ${ }^{6}$ Sabemos que é plenamente possível, e não raro acontece, que um ladrão execute um assalto apenas com um revólver descarregado.

Em sua mais profunda essência, por assim dizer, fenomenológica, enquanto coisa, a coisa revólver é receptáculo, como a jarra de Heidegger (2008, p.145-151). Por outro lado, ao contrário da jarra, não é receptáculo para a doação, para a vaza, que se deixa (pre)encher e que dá a beber, derrama na taça, ou sobre as mãos do sacerdote, dispondo céu e terra, mortais e imortais; não, o revólver é receptáculo, mas não para a vaza, e sim para a ameaça, e ameaça de morte. Por esta razão, não está aí para ser (pre)enchido, mas para provocar reserva com sua presença. Esta é a essência da ameaça: que ela não ameaça com alguma coisa, mas enquanto presença, caindo fora de consideração, como irrelevante, aquilo com o que ameaça. Receptáculo para a ameaça, simplesmente porque o revólver pode conter dentro de si uma coisa letal, quando disparada. Receptáculo, portanto, para a ameaça com disparar. $\mathrm{O}$ mecanismo, a queima, a pólvora, a cápsula, pertencem a um campo semântico instrumental, ôntico, científico, do qual prescinde a capacidade de provocar reserva do revólver. Mas esta capacidade não está no revólver enquanto objeto, que é feito de tal material ou apresenta tal mecanismo, e sim no revólver enquanto coisa e receptáculo. Pouco importa se vazio, ele traz um segredo com o qual não vale a pena apostar. A expressão que se repete pela terceira vez, "a que se sente ante", é por fim satisfeita: "essas coisas que conservando outras guardadas". Novamente, cumpre ressaltar a repetição de "coisa/coisas" e "outras [coisas]". Aliás, o ovo é, antes de 
qualquer coisa, "uma coisa", já no segundo verso da primeira estrofe do poema.

Parágrafo quarto

Na manipulação de um ovo

um ritual sempre se observa:

há um jeito recolhido e meio

religioso em quem o leva.

Se pode pretender que o jeito

de quem qualquer ovo carrega

vem da atenção normal de quem

conduz uma coisa repleta.

O ovo porém está fechado

em sua arquitetura hermética

e quem o carrega, sabendo-o,

prossegue na atitude regra:

procede ainda da maneira

entre medrosa e circunspecta,

quase beata, de quem tem

nas mãos a chama de uma vela.

Na presença, a contraposição com que o poema havia começado, entre "o ovo" e "um ovo", é finalmente superada. Mas não devemos nos apressar sobre isso. Um mero ovo, com sua presença, não é só capaz de provocar reserva em qualquer sala, mas também é capaz de despertar, de deixar alerta, por causa de certa atitude e comportamento daquele que o tenha nas mãos, não para acariciá-lo, mas para levá-lo. O ovo é um ovo em movimento, levado por alguém. Este alguém se recolhe. A precisão semântica é notável. Quando alguém tem nas mãos um ovo para levá-lo ou manejá-lo (é isto que significa aqui "manipulação"), um ritual "sempre se observa". Note-se a dupla função do verbo "observar", no sentido de perceber e no sentido de obedecer, de cumprir (o ritual). Este último sentido, o do cumprimento do ritual, é reconciliado com o sentido visual que o poema começou negando. Mas não se trata de uma reconciliação plena. Ao olho é devolvida sua dignidade se, e somente se, ele percebe a diferença em relação àquele que "leva". A contraposição é, na verdade, elevada a um outro nível.

A atitude é rigorosamente colocada num entre-lugar, entre o profano e o sagrado, entre o mortal e o imortal, entre 
o prosaico e o poético, entre o inerte e seu sentido oculto. Daí as expressões "meio religioso", "entre medrosa e circunspecta" e "quase beata". Isto é destacado pelo gesto peculiar, repetidamente advertido na palavra "jeito", ao mesmo tempo cotidiano e sagrado, de "levar" e "carregar", em que o poema parece insistir. Por isso que o ovo, como já dito, é uma coisa inteiramente adequada à própria concepção cabralina do real, pois contém em si o que o poeta precisa, a cada vez, enxergar nas coisas. Mas isso não torna o trabalho poético fácil. Pelo contrário. Ele precisa desvendar o mais sutil sentido oculto do inerte. Pois "aquele que vê" pode pretender que "aquele que leva" está em atitude alerta, porém corriqueira, típica de quem leva uma coisa profana peculiar, "repleta", isto é, totalmente desvendada, sem segredos, sem sentido oculto. Só quem o leva é que sabe, e por isso prossegue (levando) e procede (ao ritual), como quem tem nas mãos a chama de uma vela. Da precisão semântica já dissemos: a chama como elemento primitivo e sacro, como a pedra, ou a água. A precisão formal não é menos notável, afinal simétrica, entre "vela" e "leva". Quem o vê, percebe. “O ovo porém está fechado".

\section{Clarice: o ovo e seus disfarces}

O que é um ovo? Junção de ovócito e espermatozoide? Uma célula? Um reservatório genético? Um processo ou um acabamento? Alfa ou ômega? Provavelmente, não pensamos nisso quando olhamos para um ovo. Na hora da fome, ovo é casca, gema, clara e nada mais. No entanto, o texto de Clarice nos provoca, ou melhor, nos convida a "ver" um ovo "com um só olhar" (LISPECTOR, 1998, p.49). Um só golpe em que passado, presente e futuro se fundem em uma experiência arcaica do tempo que é, antes de tudo, visão e memória. Presentificações de um instante que, também, projeta o futuro: "ver o ovo é a promessa de um dia chegar a ver o ovo" (ibidem, p. 49). Estranho paradoxo de um olhar que é pré-visão de um amanhã já realizado. $\mathrm{O}$ ovo é útero em sentido mais próprio, isto é, matriz de todas as coisas e, enquanto tal, imagem de gestação, mas, também, de realidade dada: "ter uma casca é dar-se" (ibidem, p.50).

É fundamental o entendimento do "dar-se" como, por um lado, o manifesto, isto é, o objeto concreto visto sobre uma 
mesa e, por outro, o invisível processo anímico que pulsa sob o invólucro oval. "O ovo é uma coisa suspensa. Nunca pousou" (ibidem, p.50). Nesse sentido, pode-se entender porque a galinha é o disfarce do ovo (ibidem, p. 51), ou melhor, porque ela só existe para que o ovo seja preservado enquanto tal: "[p]ara que o ovo atravesse os tempos a galinha existe" (ibidem, p.51). Embora não entrando na querela sobre quem nasceu primeiro, o ovo ou a galinha, não resta dúvida de que o ovo sempre foi: "o ovo encontrou a galinha" (Ibidem, p.52, grifo nosso); poderíamos dizer que o fato de o ovo existir faz com que a galinha exista simultaneamente. A galinha é gestada do ovo e para o ovo. Ao ser, o ovo torna a galinha possível. Vale ressaltar que ser ovo de galinha ou de pássaro, ou de animal, é artifício, ou seja, modo de conservação no qual o ovo, simplesmente "ovo", se mostra enquanto grandiosidade multifacetária que torna aquele que o carrega escravo de seu peso. Quem carrega um ovo carrega uma cruz. "O ovo é o grande sacrifício da galinha" (ibidem, p.52).

Cumpre enfatizar que, em minuto algum, estamos apontando para uma visão de subserviência no sentido de nulidade. A galinha não é nula frente ao ovo, mas se realiza com e no ovo. Vejamos uma passagem decisiva para o que estamos aqui comentando:

O ovo é o sonho inatingível da galinha. A galinha ama o ovo. Ela não sabe que o ovo existe. Se soubesse que tem em si mesma um ovo, ela se salvaria? Se soubesse que tem em si mesma o ovo, perderia o estado de galinha (LISPECTOR, 1998, p.52).

O que podemos pensar a partir dessa citação? A resposta vem logo em seguida mediante a diferenciação entre "viver" e "sobreviver". A galinha não vive, ela sobrevive, ou melhor, luta por sobreviver e sua sobrevivência é o seu amor ao ovo. Se a galinha deixa de sobreviver, ela morre. A morte entendida como perda da individualidade, isto é, como descoberta do sem fundo (abyssos) constitutivo da natureza. Nesse sentido, a sobrevivência é atenção constante, ainda que inconsciente, à vida que se gesta no interior de todas as coisas. A projeção para um futuro, para um horizonte, na espera de um povir, é uma ilusão: "A galinha olha o horizonte. Como se da linha 
7 O tema da mortificação perfaz parte da obra clariciana. Benedito Nunes já ressaltou, em sua análise do conto A maçã no Escuro, que a inteligência é mortifica pelo não entendimento, a vontade pelo não-querer. Cf. NUNES, Benedito, 1973, p. 27.

8 Benedito Nunes compreende o ovo, a galinha e a narradora como figuras possuidoras de um mesmo relevo que revelam uma parábola do caráter instrumental do amor e da vida, a serviço da existência, força latente, misteriosa e cega. Cf. NUNES, Benedito, 1995, p.93. do horizonte é que viesse um ovo" (ibidem, p.53). Enquanto imagem, estamos interpretando a galinha como expressão de um destino que exige, antes de tudo, entrega e a perda de si dos que, como guardiões, sacrificam suas vidas para que a vida se faça. Perda, nesse caso, também é morte, mas uma morte ${ }^{7}$ no sentido de abnegatio, desprendimento que conduz a um tema recorrente na obra clariciana, a saber: a impessoalidade.

As galinhas prejudiciais ao ovo são aquelas que são um "eu" sem trégua. Nelas o "eu" é tão constante que elas já não podem mais pronunciar a palavra "ovo". Mas, quem sabe, era disso mesmo que o ovo precisava. Pois se elas não estivessem tão distraídas, se prestassem atenção à grande vida que se faz dentro delas, atrapalhariam o ovo (LISPECTOR, 1998, p.54).

Temos, assim, uma clara referência a uma espécie de servidão, não do tipo involuntária, mas um servir que é, acima de tudo, vigília constante contra a profanação do útero vital da existência. No texto encontramos uma alusão ao que estamos aqui dizendo: "faço parte da maçonaria dos que viram uma vez o ovo e o renegam como forma de protegê-lo" (ibidem, p.55). Nesse misto de veneração e desconhecimento, já que o ovo não é objeto de pensamento, reside a imagem do amor como participação. O amor como participação converte tudo o mais em desilusão (ibidem, p.55). É paradoxal que o amor converta tudo o mais em ilusão, mas o amor exige, ao contrário do que se imagina, pobreza: "Amor é não ter" (Ibidem, p.55). A aparição do amor no conto é estratégica porque revela o aspecto universal de um trabalho silencioso que faz das vidas particulares conexões vitais com a vida cósmica.

No nosso entendimento, a experiência do amor aqui tratada associa-se ou decorre de um modo de ver o mundo expresso na relação inicial com o ovo, que define, precisamente, um corte na escrita do texto: "comecei a falar da galinha e há muito já não estou falando mais da galinha. Mas ainda estou falando do ovo" (ibidem, p.54). Nesse momento específico do conto, galinha e narradora se metamorfoseiam ${ }^{8}$ no não reconhecimento do ovo em sua forma exterior: "De repente olho o ovo na cozinha e só vejo nele a comida. Não o reconheço, e meu coração bate" (ibidem, p.54). Assim como a galinha que se alvoroça diante do 
ovo, nas palavras de Clarice, tomando-o como algo impossível, a protagonista vivencia uma experiência de negação, no sentido de lucidez, ou poderíamos dizer de preservação contra a profanação do que, no ovo, sobre a mesa, se vela.

Encontramo-nos no ápice da experiência narrada, a saber, na confluência entre imanência e transcendência: "fora do ovo particular, fora de cada ovo que se come, o ovo não existe" (ibidem, p.54). Não existir significa estabelecer o limite que separa o visível e o invisível, o entendimento e o não entendimento. $\mathrm{O}$ ovo se dá de modo indireto nos ovos que na frigideira alimenta o indivíduo em sua cotidianidade. Diz ela:

"Pego mais um ovo na cozinha, quebro-lhe casca e forma. Ea partir deste instante exato nunca existiu um ovo. É absolutamente indispensável que eu seja uma ocupada e uma distraída" (LISPECTOR, 1998, p.55).

O conto iniciou-se com uma afirmação intrigante, mas que, a essa altura, já se torna compreensível. Voltemos, pois: "Olhar é o necessário instrumento que, depois de usado, jogarei fora" (ibidem, p.49). É chegado o momento de não ver? De que não visão estamos tratando? A narradora diz que "de ovo em ovo chega-se a Deus que é invisível a olho nu" (ibidem, p.51). Essa ideia nos faz pensar em um aspecto importante da tradição mística cristã, em particular, Mestre Eckhart, quando o mesmo, analisando a passagem bíblica dos Atos 9,8, refere-se à experiência paulina a caminho de Damasco, do seguinte modo: "quem nada vê e é cego vê Deus" (ECKARDT, 1999, p.92). No caso do conto, o contraponto entre conhecimento, esquecimento e palavra, é, uma vez mais, caminho negativo para que o ovo se mantenha protegido, como Deus que "faz das trevas sua morada" (Sl.18.12).

Se no texto bíblico, ninguém vê Deus (1Tm 6.16), no conto, quem vê o ovo não o vê, mas somente um modo seu de dar-se. Essa compreensão conduz a narradora a um esquecimento voluntário marcado pela devoção e, em última instância, uma espera de que abandonado em si mesmo ele possa voltar: "livre, delicado, sem mensagem alguma para mim - talvez uma vez ainda ele se locomova do espaço até esta janela que desde sempre deixei aberta" (LISPECTOR, 1998, p.59). Resta, assim, o não saber como abertura e reiteração do sacrifício que é viver. 


\section{Considerações finais}

Dos dois textos aqui expostos, cabe-nos pensar suas confluências e divergências. Tantos são os pontos de convergência, e igualmente numerosas as diferenças, ou mesmo as discordâncias, no conteúdo, no estilo, na abordagem e nas "conclusões" que ambos, Cabral e Clarice, realizam em seus distintos constructos literários, que um trabalho de mera "conciliação" seria impensável. Chegamos mesmo a questionar: será que algumas ideias, presentes nas obras aqui interpretadas, nos ajudam a construir a interface entre Cabral e Clarice? Na verdade, tentamos aqui, com não pouca dificuldade, estabelecer um "diálogo" possível.

Mesmo que não possam deixar de ser apresentadas sob algum traço de diferença, comecemos com as noções em comum. A primeira consiste no aspecto "vital" que o ovo comporta, o que poderia, salvo maiores determinações, ser um simples truísmo poético. Para Cabral, o peso do ovo não é o das pedras, mas é morno, vivo. No entanto, a ênfase recai sobre o "peso", sobre a suspeita de vida que o ovo oferece a um dos sentidos. Em Clarice, ainda que não de maneira direta, o ovo é a própria vida pulsante que transforma tudo em suporte para que ele seja. Uma segunda noção diz respeito ao "acabamento" que a forma do ovo expressa. No seu torneamento, o ovo revela um trabalho digno somente da natureza. Porém, se em Cabral este trabalho é externo, acabamento artesanal, em Clarice é um trabalho milenar, de gestação e geração. Uma terceira noção, também comum, se refere ao fato de o ovo não ser, embora acabado, fim, mas início. O ovo é "ponto de partida" em Cabral e, em Clarice, é princípio, no sentido grego de arkhé, ou seja, fundamento sem fundo. Uma quarta noção comum consiste na "reserva" que o ovo provoca. A presença do ovo, diz Clarice, desnuda a cozinha (Ibidem, p.50) e, para Cabral - embora não na cozinha, mas na sala - provoca uma sensação de perigo, de disparo. Não se trata de medo ou pavor, mas de uma certa suspensão provocada pela possibilidade intrínseca ao ovo de desencadear uma ação.

No tocante às diferenças, é possível começar pelo estilo e abordagem. Clarice, por um lado, vai direto ao ovo em seu caráter mais prosaico, de manhã na cozinha, e, não obstante, com a mesma imediação, esta referência se torna impossível, 
e somos transportados, tão rápido como um raio, para três milênios atrás: "Olho o ovo com um só olhar. Imediatamente percebo que não se pode estar vendo um ovo. Ver o ovo nunca se mantém no presente: mal vejo um ovo e já se torna ter visto o ovo há três milênios" (LISPECTOR, 1998, p.49). Cabral, por outro lado, começa com a mesma cotidianidade prosaica, mas vai se aproximando lentamente do objeto, num passo a passo. Cumpre destacar, entretanto, que ambos começam com o olhar.

Apesar de começar seu conto com um convite a ver um ovo "com um só olhar", na verdade não é ao sentido da visão que Clarice se refere, mas, como dissemos, ao supervisível. Porque a visão é um sentido espacial, de qualidades sensíveis como forma, figura, acabamento, espessura, etc. Assim é, por exemplo, o princípio da aproximação cabralina. Mas Clarice tem em mente uma relação, antes de tudo, temporal. “Um só olhar" significa: passado, presente e futuro em uma experiência arcaica do tempo. A casca, que designa também, apesar do sentido profundamente imemorial do ovo enquanto matriz de todas as coisas, a realidade dada, a face visível, a mera casca, também ela é, para Clarice, um algo mais invisível. É por isso que, para ela, o olhar é o necessário instrumento que, depois de usado, é jogado fora. É na relação temporal, aliás, que se funda praticamente toda a relação com a galinha, pois esta existe para que o ovo atravesse os tempos.

Correríamos um grande risco se penetrássemos nas discussões sobre a natureza metafísica ou pós-metafísica dos dois autores. ${ }^{9}$ Entretanto, devemos ao menos recordar que a poesia não pode - pelo menos em Cabral -, por compromisso pictórico, refletir sobre o ovo. Ele permanece fechado, integralmente no contorno. O conto, pelo contrário, discorre sobre o ovo. E se Cabral não diz nada, pois o ovo está fechado, contudo a narrativa de Clarice transborda em palavras para dizer a mesma coisa: que o ovo está fechado. O conto assume corajosamente o desafio de dizer o que não se deixa dizer, "o ovo é o sonho inatingível da galinha". Prova disso é o fato de que a galinha não sabe que o ovo existe e que, além disso, galinha e narradora se fundem no espanto diante da (im)possibilidade do ovo. Disso

9 Cf. GRUPILLO, 2014; BEZERRA, 2013. depreende-se, também, uma relação ambígua com o futuro: se, de um lado, o porvir é ilusão, de outro, a janela está aberta, 
no fim do conto. Seria esta a ambiguidade fundamental do guardião? Sua implacável fidelidade à coisa?

Em contrapartida, Cabral é igualmente fiel à sua ética, também implacável, de só dizer o abstrato através do concreto. Para Clarice, o dualismo não existe, o ovo são os ovos. O entendimento do ovo é ao mesmo tempo um não entendimento. Para Cabral, é precisamente as contraposições que alimentam, pouco a pouco, a proximidade, sempre assintótica, com o ovo, que nunca se quebra. Inclusive a quebra do ovo, em Cabral, não chega a ser tematizada, ficamos apenas com a ameaça. Em Clarice, a quebra do ovo é tematizada como a não existência de todo ovo.

A ética do trabalho, em Cabral, e a ética do cuidado, em Clarice, aparentemente se formam no mesmo compromisso existencial com a forma rígida, não exterior, mas em sua maneira de ser. O amor, para Clarice, revela o trabalho silencioso da vida cósmica. Em Cabral, o labor e a diligência independem da relação que estabelecem, seja de precedência ou de servidão, de ajudar ou atrapalhar, um trabalho superior. Trata-se, antes disso, de uma imitação. Se há um trabalho "cósmico" em Cabral, como nas "mil inacabáveis lixas" escondidas na água, na brisa, ele serve apenas de modelo, de ideal de pureza, de condição incansável, que o poeta emula.

Para além do metafísico, existe algo que no conto de Clarice é decisivo, mas que no poema de Cabral toma outro sentido, a saber: o religioso. Curiosamente, embora todo o conto comporte uma interpretação espiritual, entendendo a relação entre o ovo e os seus protetores ou agentes, assim chamados no texto, como uma relação entre Deus e iniciados, não há referência explícita à religião. Já no caso de Cabral, o fim do poema é claro: quem manipula o ovo tem uma postura meio religiosa de quem leva algo sagrado nas mãos.

No entanto, uma leitura superficial dos dois textos engana. A ausência de alusão à religião no conto de Clarice não deve nos levar a concluir que não há religiosidade no texto. Pelo contrário. Aspectos iniciáticos, sacrificiais e devocionais, apontam para uma experiência de transcendência imanente marcada, como já dissemos, pelo abandono e pela liberdade. No caso de João Cabral, o jeito religioso de quem manipula um ovo, não aponta para nada específico além da atenção 
dispensada a algo suspeito e repleto, frágil e delicado como a chama de uma vela. Diríamos, a título conclusivo, que o texto de Clarice aponta, desde o ovo, para fora, isto é, para o todo, enquanto que o poema cabralino aponta, desde fora, para o ovo.

\section{REFERÊNCIAS}

BEZERRA, C. O enigma da visão: Clarice Lispector e MerleauPonty. Terra Roxa e Outras Terras. v. 24, (dez 2012), pp.49-58.

. O mundo e o imundo em 'A Paixão segundo G.H.' de Clarice Lispector: aproximações neoplatônicas. In: PINHEIRO, Marcus Reis; AZAR FILHO, Celso Martins. Neoplatonismo, mística e linguagem. Niterói: Editora da UFF, 2013.

BÍBLIA de Jerusalém, A. São Paulo: Sociedade Bíblica Católica Internacional e Paulus, 1995.

BLANCHOT, M. O Espaço Literário. Rio de Janeiro: Rocco, 2011. ECKARDT, M. Sermões Alemães. v. I e II. Petrópolis: Vozes, 2008. GRUPILLO, A. O real é espesso: o materialismo pós-metafísico de João Cabral de Melo Neto. In: NATÁRIO, C.; CUNHA BEZERRA, C.; EPIFÂNIO, R. (coords.). (Im)possíveis (trans) posições. Ensaios sobre Filosofia, Literatura e Cinema. Sintra, Portugal: Zéfiro, 2014.

HEIDEGGER, M. “A coisa”. In: . Ensaios e conferências. Petrópolis: Vozes, 2008.

LISPECTOR, C. “O Ovo e a Galinha”. In: Felicidade Clandestina - contos. Rio de Janeiro: Rocco, 1998.

LISPECTOR, C. Panorama. São Paulo, TV Cultura, 01 fev.1977. Entrevista a Júlio Lerner. Disponível em: <http://www.youtube. com/watch?v=ohHP112EVnU>. Acesso em: 15 mai. 2014.

MELO NETO, J.C. de. "Considerações sobre o poeta dormindo". In: . Prosa. Rio de Janeiro: Nova Fronteira, 1997. João Cabral de Melo Neto - De Lá pra Cá. Rio de Janeiro/ São Paulo/Brasília, TV Brasil, 28 set. 2009. Disponível em: $<$ https://www.youtube.com/watch?v=2ipKKsN1Qgc $>$. Acesso em: 15 mar. 2014.

. Poesia Completa. Rio de Janeiro: Nova Fronteira, 2007.

MERLEAU-PONTY, M. O Olho e o Espírito. São Paulo: Cosac \&Naify, 2004. 
MESEL, Kátia. Recife de Dentro pra Fora. Recife: Arrecife Produções, 1997. 1 filme (15min): son., color. Disponível em: $<$ https://www.youtube.com/watch?v=asULkiyJzrQ>. Acesso em: 15 mar. 2014.

NASCIMENTO, E. Clarice Lispector: uma literatura pensante. Rio de Janeiro: Civilização Brasileira, 2012.

NUNES, B. A clave do poético. São Paulo: Companhia das Letras, 2009.

O drama da linguagem: uma leitura de Clarice Lispector. São Paulo: Ática, 1995. Clarice Lispector. São Paulo: Quiron, 1973.

SANT'ANNA, A. Com Clarice. São Paulo: Unesp, 2013.

VILLAÇA, Alcides. Expansão e limite da poesia de João Cabral. In: BOSI, Alfredo (org.). Leitura de poesia. São Paulo: Ática, 1996. WITTGENSTEIN, L. Investigações filosóficas. São Paulo: Abril Cultural, 1979.

\begin{abstract}
Representations of the Archaic: João Cabral de Melo Neto and Clarice Lispector

Dealing with two authors like João Cabral and Clarice Lispector is at least challenging. Mixing poetry and short story in a comparative analysis requires a double effort: firstly, it is necessary at the interpretation not to reduce the poetic into the merely analytic and, secondly, not to lose the poetic concision of the short story. This article has nevertheless a central axis: to reflect on the image of the "egg" present in both authors, highlighting differences and reconciliations which enable to think, from the literary point of view, a comprehension of the archaic that is precisely manifested in everyday life.
\end{abstract}

Key-words: João Cabral; Clarice Lispector; egg; archaic. 